\title{
The Blindness of Justice: An Iconographic Dialogue between Art and Law
}

\author{
Marcílio Franca ${ }^{1}$
}

'Law without symbols is sad, and life flees the barren grounds of sadness.'

Ruy de Albuquerque

1 Visiting Professor, Department of Law and Collegio Carlo Alberto, Università degli Studi di Torino, Italy. Professor of the Federal University of Paraíba (UFPB), Brazil. Alternate Judge at the MERCOSUR Permanent Review Court, in Asunción, Paraguay. Member of the International Association of Constitutional Law, International Society of Public Law, Instituto Hispano-Luso-Americano de Derecho Internacional (IHLADI) and President of the High Council of the International Law Association. The Portuguese version of this text was published in Brazil in 2011. The current version brings minor modifications, carried out after some insightful feedback. English translation by Caio Martino (Federal University of Paraíba). 


\section{Introduction}

This essay seeks to listen to the 'muta eloquentia' of visual arts, in a very specific field, namely, the plastic discourse on the eyes, the blindness and the blindfold of justice the most enigmatic feature of justice ${ }^{2}$ - throughout the last centuries of western art history. Why, over the centuries, has the goddess of justice been so often depicted with eyes open, with eyes closed, with blindfolds, without blindfolds...? What does that mean? What is the reason for these changes? These are the central issues of this text. Images shape powers, knowledge and invisible arguments, making present all which is many times absent ${ }^{3}-$ above all in those historical times when printed language was still not available to diffuse ideas. ${ }^{4}$ Therefore, the immediate objective of this text is to better understand law and better understand the art that speaks of law.

Many are the juridical themes apprehended by visual arts. Although this writing concentrates merely on the visual representations of justice - or, more precisely, on just one element (the blindfold) of the very same representations -, themes such as law, trials, sentences, courts, judges, lawyers, codes, treaties, juridical institutions or legislators have always been profusely found in arts in general and especially in visual arts. By electing the iconography of justice as an object of investigation,

${ }^{2}$ Christian-Nils Robert, Une Allégorie parfaite: La Justice: vertu, courtisane et bourreau (Genève: Georg, 1993), 13.

3 Lynda Nead and Costas Douzinas, Law and the Image: The Authority of Art and the Aesthetics of Law (Chicago, Ill.; London: University of Chicago Press, 1999), 37.

4 Robert, Une Allégorie parfaite, 10. 
this chapter attempts to capture how it is an abstract concept (justice) that is central to the world of law has been so many times apprehended and visually reproduced in the history of juridical-political thinking. Here, the iconography of justice can represent the pictorial material relating to or illustrating the idea of justice and, thus, is a key element to provide evidences towards identification, description, and the interpretation of the notions of justice throughout the centuries.

As cultural manifestations that show man's 'relationship with that which surrounds him ${ }^{5}$, art and law have always been close throughout history. Therefore, the use of arguments, narratives and artistic knowledge to better understand arguments, narratives and juridical knowledge is not unusual, nor is it a recent phenomenon. It is fair to acknowledge, however, that, along with modernity, when common sense came to see human reason as the only objective measure of all things (logocentrism), a growing distance between art and law came to exist, which only regained power in the twentieth century. Especially due to juridical positivism, common sense accepted and diffused the idea that juridical science would be, above all, a logical science of Cartesian interpretation of rational and objective texts, with no room for semantic uncertainties, emotions or even some irrationality of art and aesthetics.

As pointed out by Stephan Prinz, for a great period of time law was understood as an exclusively textual science (Textwissenschaft) whose strength would reside in the

5 Meyer Schapiro, Mondrian: a dimensão humana da pintura abstrata (São Paulo: Cosac \& Naify, 2001), 8. 
purest interpretation of legal texts, with no room whatsoever for art-like conceptual openness, plurivocity, polysemy, anarchy or even some irrationality. ${ }^{6}$ To the late Prof. Cornelia Vismann, jurists are really afraid of images: they suffer from imagophobia. ${ }^{7}$ This essay is meant to bridge this distance between arts and law, showing the possibilities of an aesthetic discourse of juridical science, which is not only centred around the logocentrism and nomocentrism of positive law, but one discourse that registers its conviction that law is very far from being only 'sola escriptura'.

\section{Jus e(s)t Ars}

For didactic reasons, at least four planes of deep interaction between art and law can be accounted for: 1) law as an object of art, that is, all those instances when justice and law were the subject of masterpieces by great artists of painting, literature, cinema, drama, and so on; 2) art as an object of law, that is, the countless cases when law set itself to regulate, discipline, protect, limit or shape the themes, works, liberties or rights of artists; 3 ) art as a right, with its many discussions on the right to culture, the right to the protection of artistic heritage, and the exercise of artistic freedom of expression; and, finally, 4) law as art, which gives rise to the classic definition of law as 'the art of goodness and equity' ('ius est ars boni et aequo',

${ }^{6}$ Stephan Prinz, Juristische Embleme: Rechtsmotive in den Emblemata des 16. bis 18. Jahrhunderts (Berlin: Lit, 2009), 1.

7 Cornelia Vismann, 'Image and Law - a Troubled Relationship', Parallax 14, no. 4 (2008): 1. 
according to Celsus) and its occasional relations with the grammars of law as science and law as technology. This essay focuses mainly on the first dimension above.

As can be noticed, such relationships take place in an extrinsic perspective of the dialogue between art and law, and are more directed to the thematic contents of law and art. This quadripartite classification, however, ignores that novels, essays, poems, plays, paintings, engravings, sculptures, movies, music sheets and architecture may always create innovative juridical arguments and contents, even if they do not indicate that law is their major object of reflection. Therefore, there is a fifth plane of interaction between art and law: art that speaks to law even though it does not speak about law. Art and aesthetics - due to their non-dogmatism, dynamic complexity, refined understanding of the world, openness and creativity - always have a lot to say to law, even when words are not used. Not by chance the greatest Roman jurists, for example, were always seeking the elegantia juris - an aesthetic sense of juridicity, guided by a component of beauty and elegance for the juridical forms. ${ }^{8}$ In addition, novels, poems, plays, paintings, engravings, sculptures, movies and architecture may also create new juridical arguments and contents, as they disorganise convictions, undo certainties, liberate possibilities, and anticipate the future. ${ }^{9}$

It is not a coincidence, then, that the oldest book on the mute eloquence of images, the Emblematum Liber

8 Jerome Frank, 'Words and Music: Some Remarks on Statutory Interpretation', Columbia Law Review 47, no. 8 (1947): 1259.

9 François Ost, Contar a lei: as fontes do imaginário jurídico (São Leopoldo, RS: UNISINOS, 2007), 13. 
(Emblem Book) was published in 1531 by the Milanese Renaissance jurist Andreas Alciatus (1492-1550). ${ }^{10}$ The book by Alciatus is considered the milestone of a new discipline, 'Emblematics', which gathers literary and image elements. Ever since jurist Andreas Alciatus published his Emblematum Liber, in 1531, more than a few scholars under diverse fundaments and points of view - have attempted to highlight these relationships between artistic discourses and juridical categories. In fact, one of the first disciplines to care about systematising, organising and exposing such knowledge this way was, undoubtedly, the 'juridical symbolism' (or iurisprudentia symbolica) which dates back to the work of art of Italian Giambattista Vico, and whose greatest exponents are Germans Jacob Grimm and August Ludwig Reyscher, Frenchmen Jules Michelet and Joseph Pierre Chassan and Portuguese Theóphilo Braga. In his work Essai sur la Symbolique du Droit, Chassan defines the reasons and the object of this new discipline named 'juridical symbolism' like this:

'Law, in its external manifestations, has not always exclusively coated the form of the word or alphabetic writing. To be understood and retained by the rude intelligence of the uneducated men of primitive times, law needed sensitive images, figurative representations and physical signs to speak to the eyes and to imagination. These real or animated signs were named symbols. Herein we call them juridical symbolism, to better characterise their specialty. The science that teaches the formation and origin of such symbols - and which, using the materials provided by erudition, created on symbols, including law in

${ }^{10}$ Nead and Douzinas, Law and the Image, 7. 
use, a body of doctrine, altogether philosophical and practical, a set of rules and precepts that lead to explaining the symbols in general and to knowing each symbol in particular - is called juridical symbolism.' ${ }^{11}$

For a very long time law was 'multimedia'. In many occasions in history, law used symbols and images to be disseminated and understood - especially over a long period when illiteracy was dominant and the press was inexistent, inaccessible or costly. Especially between the Middle Ages and modern times, the dignity and the weight of images were great, so much so that important juridical manuscripts were richly illustrated, forming the relevant set of images now known as 'iurisprudentia picturata'. ${ }^{12}$

In the early twentieth century, the studies on symbols, images, objects and emblems associated with law and justice greatly developed in Germany, with the birth of a new historical-juridical discipline named 'Rechtsarchäologie' ('juridical archeology’), founded by Professor Karl von Amira, of the University of Munich. Especially between the 1910s and 1930s, 'juridical archeology' provided great contributions in this field, through seminal works to comprehend juridical imagery. Today, the theme still

${ }^{11}$ Joseph-Pierre Chassan, Essai sur la symbolique du droit (Paris: Videcoq fils aîné, 1847), 1-2.

12 Robert Jacob, Images de la justice: essai sur l'iconographie judiciaire du Moyen âge classique (Paris: Léopard d'or, 1994), 11. Two of these manuscripts, the Decretum Gratiani (Decree of Gratian, twelfth century) and the Sachsenspiegel (literarily meaning Saxon Mirror, thirteenth century), contain those which are considered the founding images of juridicity. Great artistic and juridical relevance is also given to the Hamburger Stadtrecht collection, 1497. 
enjoys the special attention of the Max-Planck-Institut für Europäische Rechtsgeschichte, Frankfurt (Germany). After the 1990s, the rise of several versions of the movement 'Law and...' - such as Law \& Society, Law \& Literature and Law \& Humanities - inspired another wave of dissemination of aesthetic-cultural studies on the juridical phenomenon in the English language. ${ }^{13}$ At the same time in Europe, the dissemination of historical-aesthetic-cultural studies on justice and law also led to the constitution of a solid French-speaking school of 'juridical iconology'. Strongly influenced by information technologies, juridical informatics and the multimedia character of the contemporary culture, a brand-new discipline started to be shaped in Austria, Switzerland and Germany in the early twenty-first century: 'Rechtsvisualisierung', that is, 'juridical visuality' (or 'BilderRecht', or even 'Visuelle Rechtskommunikation'). This discipline focuses on studying the design of juridical information and the multiple modalities of communication of the juridical phenomenon throughout history - from richly-illustrated medieval manuscripts to contemporary 3-D digital information. ${ }^{14}$ 'Rechtsvisualisierung' is a direct heir to an epistemicmethodological trend that completely spans the whole range of contemporary human and social sciences: the renewed role given to images in current society, which is

13 Anna Di Robilant, 'The Aesthetics of Law', Global Jurist Advances 1, no. 2 (2001): 2.

${ }^{14}$ Colette R. Brunschwig, 'Rechtsvisualisierung: Skizze eines nahezu unbekannten Feldes', MultiMedia und Recht 12, no. 1 (2009): IX-XII. 
described by Boehme-Nessler as 'iconocracy.'. ${ }^{15}$ In other words, more and more human and social sciences have used images to understand and explain the world and law is not immune to this trend.

The iconophilia of contemporary human and social sciences is, above all, due to three factors: 1) easy access to ancient images, due to technological improvements in preserving, digitising, storing and researching great image banks; 2) easy production and dissemination of new images, also due to new technologies for production and dissemination (among which are YouTube and Flickr); and, finally, 3) the countless images that are continually produced, consumed and discarded in the most accessible media channels, such as cable TV, newspapers, magazines, websites, blogs, mobile phones, and so on, which has led people nowadays to an essentially visual way of thinking. One more issue can be added to these three factors, which is the fact that communication via images is always faster than communication through text, and speed is undoubtedly a central concern of the world today. ${ }^{16}$

In this scenario of excessive visuality in contemporary culture it is paradoxical that one of the most frequent attributes of iconography of justice is - still today - the blindfold. This is one of the main reasons why this essay is dedicated to the theme of the blindfold and the blindness of justice and not any other of the many controversial and

${ }^{15}$ Volker Boehme-Nessler, BilderRecht: die Macht der Bilder und die Ohnmacht des Rechts (Heidelberg: Springer, 2010), 56.

${ }^{16}$ Boehme-Nessler, BilderRecht, 64. 
complex aspects of the iconography of justice, for example, the dominant gynecocracy in its representations. ${ }^{17}$

All these theoretical nuances - from the symbolism of law to juridical visuality - are nothing but attempts to comprehend that which Professor Rodolfo Sacco once defined as 'mute law', that is, the very important unwritten or unspoken dimension of law. ${ }^{18}$ In this sense, contradictory as it may seem, by rescuing very old historical images of art and law - to be seen in the following chapter, this essay - far from fitting into a melancholic laudatio temporis actii - matches the most contemporary way of thinking of social and human sciences: the study of the rhetoric of iconosphere (or Bilderwelt) in which we are all immersed. Iconosphere (or Bilderwelt) is to be understood as the immense and complex network of image meanings which we are submitted to in our 'Media Age'.

\section{Blindfold and Eye in the Iconography of Justice}

The previous sections demonstrated the long-lasting familiarity between art, image and law. It is now time to examine the juridical iconography throughout past centuries in search of an answer to the central question of

17 Robert, Une Allégorie parfaite, 45-51.

18 Rodolfo Sacco, 'Mute Law, The American Journal of Comparative Law 43, no. 3 (1995): 455-458, doi:10.2307/840648. 'In its open texture it is necessary to interpret silence, the unsaid. Law does not always make a sound. Most of the times it just whispers, waves, suggests with a task. Most of the times, sound is reduced to the perception of silence, of that which was half-said" - Mônica Sette Lopes, Uma metáfora: música \& direito (São Paulo: LTr, 2006), 131. 
this text: how, when and why did the iconographic representations of justice start to have a blindfold over the eyes if, for more than 2000 years, clear unblocked sight was one of the main features of justice?

Nowadays, the blindfold is a recurrent element in the iconography of justice. Among the many paradigmatic representations of justice and judiciary power, it is enough to remember the austere and solemn sculpture in granite by Alfredo Ceschiatti, built in 1961, on show at the entrance of the Brazil's Federal Supreme Court in Brasília. However, as pointed out by Erwin Panofsky, the figure of the blindfolded justice is a very recent humanistic creation in the history of art. ${ }^{19}$ For many centuries, justice was associated with a crystal-clear view of the facts; after all, sight was essential for justice to manage well the sword and the scale, two other attributes with which it is frequently represented.

Geneva, Switzerland, late eighteenth century: due to a constitutional provision during the revolutionary government of the Republic and Canton of Geneva, between 1792 and 1796, the city's attorney general bore a round badge of golden brass about $10 \mathrm{~cm}$ in diameter that reproduced a big open eye in high relief, to refer to the constant and tireless alertness of law. ${ }^{20}$ At that time, the winds of

19 Erwin Panofsky, Studi di iconologia: i temi umanistici nellarte del Rinascimento (Torino: Einaudi, 1999) 151. In fact, there is no image of justice wearing a blindfold from before the late fifteenth century - Robert Jacob, Images de la justice: essai sur l'iconographie judiciaire du Moyen âge classique (Paris: Léopard d’or, 1994), 232.

${ }^{20}$ Here is a description of this item, according to the catalogue written by historian of art Waldemar Déonna, Director of the Museum of Art and History of Geneva at that time: "N. 819 (anc. 86) - Insigne de 
'liberté, égalité et fraternité of the French Revolution had started to blow all over the European continent and the omniscient 'eye of the law' was the guarantee of the omnipresent, impartial, secular and objective Rechtsstaat. ${ }^{21}$ The popular saying 'das Auge des Gesetzes wacht' - 'the eye of law is watching', was perpetuated by the poetry of Friedrich Schiller. ${ }^{22}$

Much more than a poetic metaphor or a mere saying, the image of a tireless 'eye of the law' was in fact evidenced in the text of article VI of the Declaration of the Rights of Man and of the Citizen, of August 26, 1789:

The law is the expression of the general will. (...) All the citizens, being equal in its eyes [law's eyes], are equally admissible to all public dignities, places and employments, according to their capacity and without distinction other than that of their virtues and of their talents. ${ }^{23}$

In his famous painting of 1789 , which is an allegory of the Declaration of the Rights of Man and of the Citizen, French painter Jacques François Le Barbier depicts the eye of the

procureur général sous le gouvernement révolutionnaire de Genève en 1794. Sur une plaque circulaire de laiton, oeil grand ouvert, en relief, symbole de surveillance constante. Diam.: 0,10." - Waldemar Deonna, Collections archéologiques et historiques: Moyen Age et temps modernes: Ville de Genève, Musée d'art et d'histoire (Genève: Musée d'art et d'histoire, 1929), 104.

${ }^{21}$ Michael Stolleis, L'Eil de la Loi Veille - Histoire d'une Métaphore (Paris: Mille et Une Nuits, 2006), 38-39.

22 Verse 301 of the poem Das Lied von der Glocke (1800), by Schiller.

23 "Article 6 - La loi est l'expression de la volonté générale. (...) Tous les citoyens, étant égaux à ces yeux, sont également admissibles à toutes dignités, places et emplois publics, selon leur capacité et sans autre distinction que celle de leurs vertus et de leurs talents." 
law in a special position. That painting shows France holding the broken chains of tyranny and the spirit of the French nation holding the sceptre of power, under the bright and severe look of law/reason. It must be said that 'the eye of the law' was not a modern invention nor was it a creation of the 1789 Revolution, but rather it is a longlived cultural constant in the Hellenistic-Roman-Christian world. Long before the French Revolution, 'the eye of the law' or 'the eye of justice' - alert and controlling was an image of great symbolic value in Europe, be it in Greek-Latin numismatics and statues or in medieval illuminations. ${ }^{24}$

Nearly two thousand years before poet Schiller and painter Le Barbier, the figure of an observant eye of justice (dikès ophtalmós or iustitice oculus) had been evoked by Greek poet Amiano Marcelino: 'Vigilavit Iustitiae oculus sempiternus', or 'the eternal eye of justice has watched'. ${ }^{25}$ In 1515, at the height of Italian Renaissance, the Mantuan humanist Giovanni Battista Fiera published an interesting pamphlet, in the form of a fictitious dialogue between Momus $^{26}$ and the painter Andrea Mantegna (who had died nine years before ${ }^{27}$. In this text, after collecting the impressions of justice on the most varied traditions, and

${ }^{24}$ The image can be seen here: http://goo.gl/E2QL9w.

25 Stolleis, L'Eil de la Loi, 55-56.

${ }^{26}$ In Greek mythology, Momus - Sarcasm - was the god of irony, mockery, and scoff, insistently critical of the works and deeds of others.

27 Mantegna was commissioned by Pope Innocent VIII to decorate a chapel at the Vatican with an allegory of justice, which made him interested in the theme of painting justice (Battista Fiera and James Wardrop, De iusticia pingenda: a dialogue between Mantegna and Momus = On the painting of justice (London: Lion and Unicorn Press, 1957), 10-11 and 28. 
conducting a deep philosophical and theological reflection, Battista Fiera tries to demonstrate the best way to depict justice. In this pamphlet titled De Iustitia Pingenda or 'On the Painting of Justice', Battista Fiera indicates that one of the ways of representing justice is a woman's body with a huge eye in the middle of her face, or perhaps with a third eye on the back of her neck to amplify eyesight, or even with multiple eyes, similar to the mythological figure of Argus Panoptes, the Greek hundred-eyed giant hound. ${ }^{28}$ To Battista Fiera good eyesight was the key to a more precise discernment of justice.

In Cesare Ripa's classic work Iconologia, which collects and describes a number of images in several cultures and contexts, the author writes in harmony with Battista Fiera and refers to justice (according to the indications of Aulo Gellio), as a lady 'with very sharp eyes. ${ }^{29}$ Following this argumentative line, in his baroque painting Allegoria della Giustizia, found at the Palazzo Bianco in Genoa, Genoese Giovanni Andrea de Ferrari added a third eye to the image, right in the central upper part of the armour that protects the chest of the goddess of justice - still in the first half of the seventeenth century. Below the sword

28 Fiera and Wardrop, De iusticia pingenda, 29-31. Adriano Prosperi, Giustizia bendata:percorsistoricidi un'immagine (Torino: G. Einaudi, 2009), 7. In Greek mythology, Argus was Hera's hound - whose task was to watch over Io, one of Zeus' lovers -, and was killed by Hermes by order of Zeus himself. To honour her dog, Hera took the hound's 100 eyes and put them on the tail of the peacock, an animal consecrated to her. Panoptes means 'that which sees all', because during sleep Argus would close only 50 eyes while the other 50 remained vigilant.

29 Cesare Ripa, Iconologia (Roma: heredi di Gio. Gigliotti, 1593) 108. 
of justice lies the large book of law, which reads 'inconcussa vigeat. ${ }^{30}$

Some decades later in the seventeenth century, the radical opposition between the clear sight of justice and negative biased blindness was the central theme of the drawing Partiality by Hubert François Bourguignon (aka Gravelot) and Charles-Nicolas Cochin. ${ }^{31}$ As a matter of fact, the lack of sight was an element common to many medieval and Renaissance allegories, all of which with a strong negative connotation: death, ambition, greed, wrath, impetus, ignorance and the Synagogue.

The object of a refined and delicate technique of illumination, the eyes of justice are also the core theme of an anonymous eighteenth-century painting, on show at the Rijksmuseum, Amsterdam. ${ }^{32}$ Special interest in this Netherlands version of Justitia is aroused by the eye-shaped medallion between the fingers of the goddess and the absence of swords or scales in the painting.

Another exuberant eye-shaped medallion, similar to that seen at the Rijksmuseum, Amsterdam, was painted by the Lutheran Scandinavian artist Mathias Blumenthal in his Justitia Majestata (1762), currently in the collection of the Bergen Art Museum, Norway. ${ }^{33}$ A direct reference

${ }^{30}$ See the picture here: https://goo.gl/PBgSTv.

31 Drawing by Gravelot (Hubert François Bourguignon) and CharlesNicolas Cochin published in Charles-Étienne Gaucher, Iconologie ou Traité des Allégories et Emblèmes (Paris: Lattré, 1791?, tome 4) $2 \mathrm{v}$. In the City Hall of Basel, northern Switzerland, there is a fresco by $\mathrm{H}$. Bock, where partiality is depicted with eyes wide open. The image is reproduced in Robert, Une Allégorie parfaite, 50.

32 Picture here: https://goo.gl/E0LhTa

${ }^{33}$ Picture here: https://goo.gl/9sAAYd. Apart from painting the rich Justitia Majestata, commissioned by the magistrates of the city of 
to this necklace in the shape of a bright eye, as an ornament of justice, is found in the work of historian Waldemar Déonna: 'justice (...) wears a necklace with a sculpted eye around her neck'. ${ }^{34}$

It must be said that this plastic conception of justice endowed with bright open eyes spread outside the European boundaries. In fact, a remainder of this visual strategy is the sculpture of justice located on top of the roof of the Museu da Inconfidência, Ouro Preto (Minas Gerais, Brazil). ${ }^{35}$ The piece, author unknown, is possibly from the eighteenth century, when Ouro Preto was still named Vila Rica and it was the capital of the Brazilian colonial gold rush.

From the classical tradition all the way through the Middle Ages up to the European Renaissance (and up to the French Revolution, in some places), the image of justice was always associated with crystal-clear, sharp, unblocked sight, bound to inspire reverence and fear. ${ }^{36}$ Limpid vision was, then, the greatest trait of justice. Representing justice any other way would only be possible in satire or criticism. Acid critique, for instance, was the character of the woodcut ascribed to Albrecht Dürer in the satirical poem 'Das Narrenschiff'(Ship of Fools), by

Bergen (Norway), Mathias Blumenthal also wrote a detailed manuscript on the symbolism of every bit of his painting. The originals of this precious and unique document (Beskrivelse og kort Explication over Det Skildrede Emblematiske Stykke til Raad-Stuen) as well as its version in English may be seen at www.euarchives.org or at the Library of the University of Bergen.

34 Waldemar Déonna, Le Symbolisme de l'Eil (Paris: E. de Boccard, 1965), 286.

35 Here: https://goo.gl/DWPDwr.

36 Panofsky, Studi di iconologia, 151. 
Sebastian Brant, published in 1494; this illustration is the first time in which justice is seen with a blindfold on ${ }^{37}$ In his poem, Sebastian Brant - professor at the Law School of Basel and devoted catholic - describes a few more than a hundred follies and vices of the society of that time, each one ascribed to a fool. During the poem, all these fools are locked into a large vessel - similar to what Noah did with animals in his arc - for an imaginary trip to an island called Land of Fools. In this unique and isolated picture, ${ }^{38}$ Albrecht Dürer depicts excessive litigation, abuse of process and the vice of the powerful 'men of justice' of hiding the truth in vain subterfuge. Dürer shows one of Brant's fools - wearing the jester's traditional hat with rattles and balancing on a sharp tool to card wool - putting a blindfold over the eyes of justice (shown with the traditional sword and scale). Justice, who was supposed to be able to see, cannot see already due to the humiliating obstacle produced by the 'Prozeßnarren', the cunning 'process fools. The picture by Albrecht Dürer illustrates section LXXI (Quarrelling and going to court) of the long poem by Sebastian Brant, that refers to such process fools this way:

'I will now speak of the irrational ones who, on any subject, want to file suits (...) Many make more money on a case than their daily pay, and think they can cover the eyes of truth and prevent the judgement

37 The first to point out the primacy and the novelty of this woodcut ascribed to Albrecht Dürer in Das Narrenchiff was Ernst von Möller, "Die Augenbinde der Justitia', Zeitschrift für Christliche Kunst 18, no. 4, (1905): 107-122. This claim has never been disputed ever since by any iconologist of justice.

38 See the picture here: http://goo.gl/D9dSfg. 
to be over shortly. I wish that those who are fond of quarreling in court could have their asses brushed with a heavy rake'39

Bruno Lacerda adverts that the gesture of putting the blindfold over the eyes of justice, mentioned by Brant and depicted by Dürer, has a special meaning in medieval culture:

'Covering the eyes of justice was, at that time, easily associated with humiliation, contempt, mockery. The blindfold handled by the jester not only prevents her from seeing, but 'disfigures her, compromises her identity, leads to a kind of blindness that means losing sense. May we remember the biblical image of Christ [face covered], insulted and humiliated by the Jews.' ${ }^{40}$

At this point, it is necessary to remember that the buffoons or jesters, insane as they were, were the ironic voice of conscience that, laughing and making others laugh, heavily criticised the institutions around them. ${ }^{41}$

In the same line as Brant's severe criticism of the lack of sight of justice, an image dated 1550 by Dutch artist Dirk Volkertsz Coornhert, currently at the Achenbach Foundation for Graphic Arts (San Francisco, USA), shows blindfolded justice falling off a restless horse. ${ }^{42}$ With her eyes covered, justice is ridiculed, criticised and

39 Sebastian Brant, A nau dos insensatos (São Paulo: Octavo, 2010), 205.

40 Bruno Amaro Lacerda and Mônica Sette Lopes, Imagens da justiça (Sao Paulo: LTr, 2010), 31. It is also worth remembering that those who were hanged and decapitated had their eyes covered - Robert, Une Allégorie parfaite, 92.

${ }^{41}$ Michel Foucault, História da loucura na idade clássica (São Paulo: Perspectiva, 1978), 13 and ff.

42 See the picture here: https://goo.gl/Jd4cYT. 
humiliated. Another very strong image of social criticism to justice's lack of sight is the work of Danish contemporary Jens Galschiøt, entitled Survival of the Fattest, from 2002. This huge copper sculpture ${ }^{43}$ - shows justice represented as an enormous obese western-looking lady, with her eyes shut, atop the shoulders of a pitiable African figure. Indifference and social alienation of justice are underscored by her lack of sight and by the imbalance of the tiny scale she has in her right hand.

Justice, many times equipped with a sword and scale, should therefore be able to see, so that freeing her from the uncomfortable blindfold would be the State's duty. In early twentieth-century Germany, the government passed a norm that forbad any and all representations of blindfolded Justice at courts under construction. ${ }^{44}$

The farsighted and alert eye of justice, so many times reproduced in the political-juridical iconography of western art, is nothing but a lay representation of the vigilant 'eye of god' of the major monotheist religions, which, during absolute monarchy, was appropriated and secularised as the 'eye of the king', who was the worldly representative of the power and justice of God. To medieval jurists, justice was (with)in God and, as time passed, God himself delegated justice to his earthly representatives: the monarchs. ${ }^{45}$ Through a long process of secularisation

${ }^{43}$ See the sculpture here: http://goo.gl/swwuG0. The United Nations Climate Change Conference - COP15 -, took place in Copenhagen, Denmark, between 7 and 18 December 2009.

${ }^{44}$ Ministerialerla $\beta$ of January 18, 1907, apud Waldemar Déonna, Le Symbolisme de l'Eil (Paris: E. de Boccard, 1965), 289.

45 Prosperi, Giustizia bendata, 16-17. 
of theological concepts, 'deo est rex' and 'rex est lex' from before the French Revolution were followed, after the Storming of the Bastille, by 'lex est rex', in such a way that monarchic absolutism was followed by some 'legal absolutism', originating a nearly religious cult of law and justice in the modern states that were starting to be formed. ${ }^{46}$

The magnificent copper engraving by Albrecht Dürer, Sol Justitioe, of 1498/1499, translates this political-theological confluence between the divine and the secular in the representation of a justice that sees all; a justice in which the sacredness of the look of the State-judge mingles with the sacredness of the look of God. ${ }^{47}$ This engraving by Dürer also raises an additional interesting argument: justice is sitting on a lion - a traditional embodiment of power which reminds us that omniscience - of the eye of the law, the eye of God, or the eye of the king - presupposes omnipotence - of law, of God himself or of the king. That painting by Le Barbier on the Declaration of the Rights of Man and of the Citizen, mentioned above, also depicts the theological root of the eye of the law, very much so that the French painter included the eye of the law within a Trinitarian triangle, an old symbol of the Christian Holy Trinity. ${ }^{48}$

46 Robert, Une Allégorie parfaite, 34. All this modern process of secularisation of medieval theological concepts constitutes precisely the central thesis of Carl Schmitt's "political theology".

47 Here: https://goo.gl/3mbXiN. One reference to the "sun of justice" was present at the Bible (Malachi 4,2): "But for you who fear My name, the sun of righteousness will rise” (...)." - Déonna, Le Symbolisme de l'Eil, 279. The same connection between human justice and divine justice can also be noticed in the painting Justitia Majestata by Mathias Blumenthal.

48 Déonna, Le Symbolisme de l'Eil, 285-286. 
It can be noted, then, that the presence of the eye that sees all in the modern juridical imagery was not by chance. As a matter of fact, images, myths, and metaphors relative to the eye and sight were always in the spotlight in the culture of humankind: the blind clairvoyant Tiresias; the myths of Narcissus, Cupid and Medusa; the tragedy of Oedipus; the wife of Lot becoming a pillar of salt in the Bible; Orwell's 'big brother' or even the monk Jorge of Burgos, the wise blind librarian of The Name of the Rose. Shortly before his death in 1958, French art historian Waldemar Déonna concluded the manuscript of a beautiful and profound study on the symbolism of sight, published posthumously. In that text, an encyclopedic work of research, Déonna points out:

'Of all organs of sense, the eyes are really the most precious. (...) Seeing is getting to know the environment, it is knowledge. It is possessing the world, dominating it; it is 'power' $(. . .)^{3}{ }^{49}$

From 'windows to the soul' to 'mirrors of the world', the symbolic power of the eye has translated, since classical antiquity, the struggling dichotomy between essence and looks, interior and exterior, superficiality and profundity, empiricism and metaphysics. ${ }^{50}$ This tension between positive and negative in what the look means was to have an impact on the image of justice, especially on the contrast between the Anglo-Germanic Protestant world and the neo-Latin Catholic world. It is precisely not to be deceived by the sensitive appearance of things that justice

\footnotetext{
49 Déonna, Le Symbolisme de l'Eil, 1-2.

50 Stolleis, L'Eil de la Loi Veille, 54.
} 
will be represented, from the sixteenth century on, with a blindfold, in central urban Protestant Anglo-Germanic Europe, firmly confronting the idea of the 'eye of justice' predominant until then.

The image of blindfolded justice, in the sense that the blindfold is a positive sign of its independence, incorruptibility, critical distancing, proportionality, moderation and impartiality before the parties, was first seen around 1531 in one edition of the Wormser Reformation, a popular consolidation of Imperial Germanic municipal laws, ${ }^{51}$ originally written in the free Imperial city of Worms, in 1498. In the image taken from the 1531 edition, published in Frankfurt by the printer, engraver, book shopper and editor Christian Egenolph, justice is blindfolded and, apart from the traditional sword, bears a balanced scale between a rich a poor man. ${ }^{52}$ It is interesting to notice that that was the beginning of the long process of positivation and secularisation of the traditional Custom law or Canonical law, greatly influenced by the Protestant Reformation and Humanism. It is in this context of formation of the European ius commune, in which law starts to escape the influence of the Pope and of the Holy Roman Empire, that the blindfold on justice's eyes starts to have the positive status of impartiality in European iconography. Interestingly, for its influence in Protestant iconophobia, justice's lack of vision, that for so long had been a sign of inferiority or mockery, started to be interpreted in a positive light: as she is not able to see, justice does

51 Franz Wieacker, História do direito privado moderno (Lisboa: Fundação Calouste Gulbenkian, 1980), 211-212.

52 von Möller, 'Die Augenbinde der Justitia', 115. 
not risk being seduced, deceived or even corrupted by the appearance of images, and is then able to reach unbiased verdicts..$^{53}$ Once an instrument of disorientation, the blindfold is now an instrument of orientation.

As of the publication of that image in the 1531 edition of the Wormser Reformation, the blindfold (with a positive connotation) becomes incredibly well-known in a multitude of villages, counties, duchies, and so forth. It also became popular in artistic manifestations, especially in Protestant bourgeois urban areas of central and northern Europe, as a symbol of secularity, impartiality and objectivity. ${ }^{54}$ Interesting examples of this period are engravings of the Flemish artisan Cornelis Bos, Iustitia et Prudentia, 1537,,$^{55}$ and Cornelis Matsys, also titled Iustitia et Prudentia, 1538. ${ }^{56}$ Both works let out the solemn antithesis between justice's obliterated sight and the very sharp sight of prudence always depicted between mirrors and serpents. The serpent and the mirror are recurrent in the allegory of prudence. The serpent, cunning, silent, discreet, with a penetrating stare, is the symbol of knowledge associated with a model of vigilance and discernment. The mirror, in turn, symbolises self-knowledge, the careful look around, the reflection upon one's own acts.

${ }^{53}$ Nead and Douzinas, Law and the Image, 24. According to Cesare Ripa's description, "executive justice" would be a "donna, vestita di bianco, habbia gli occhi bendati (...). Si veste di bianco, perche il giudicio deve essere senza macchia (...), tenendosi gli occhi bendati, cioè non guardando cosa alcuna, della quale sadopri per giudice il senso, nemico della ragione" -Ripa, Iconologia, 108.

${ }^{54}$ von Möller, 'Die Augenbinde der Justitia', 118-120.

55 Picture here: https://goo.gl/5ytM97

56 Picture here: https://goo.gl/USZWpl 
In 1549 , the idea that the blindfold would represent the judge's incorruptibility and neutrality was assimilated and reproduced in a Spanish edition of Andrea Alciato's Emblemata, printed in Lyon by Macé Bonhomme and Guillaume Rouille, and possibly illustrated by Pierre Eskrich or Vase. In the emblem In Senatum boni Principis, the figure of a blindfolded prince conducting the discussions at the senate with impartiality translates the idea of the true 'good government. ${ }^{57}$

As time passed, blindfolded justice stops representing criticism, a joke or mockery and starts to represent a topographic and institutional rupture of the urban Protestant bourgeois iconoclast and pioneer man in terms of the civic organisation of Central Europe with that medieval, extremely personal, subjective, custom-law, agrarian, religious justice, concerned with appearances. New times call for new muses ${ }^{58}$ in such a way that blindfolded justice is now a symbol of the temporal and collective power of the borough. Thus, to signal and celebrate this rupture, blindfolded justice is then exposed in many public places, indoors or outdoors, such as markets, city halls, official salons, squares and fountains, however, always away from churches and convents, across an area of land extending from Siena, in northern Italy, to Belgian Flanders. ${ }^{59}$

It is worth mentioning the décor of the justice halls in public buildings, which go through an aesthetic revolution: they lose the 'anachronic' biblical images such as the

\footnotetext{
${ }^{57}$ Picture here: http://goo.gl/K1OVqw. Prosperi, Giustizia bendata, 43.

58 von Möller, 'Die Augenbinde der Justitia', 110.

59 Robert, Une Allégorie parfaite, 114.
} 
crucifixion of Christ, doomsday or Solomon's judgement and adopt a desacralised iconographical repertoire that associates justice with civic, bourgeois and secular virtue. This new model of allegory can be seen, for example, in the exuberant Fountain of Justice sculpted by Hans Gieng in 1543, installed right in the civic centre of the Swiss city of Bern. ${ }^{60}$ Another beautiful representation of blindfolded justice is Pieter Bruegel's engraving Iusticia, 1559. In this work, Bruegel created a panel of violent penal punishments and included justice with a blindfold (she is blind to the tortures, as well) in the centre of the borough. The caption is ironic: 'the objective of law is either to correct those it punishes, through a sentence, make other people better, or extinguish evil so that others can live a safe life', which well summarises the secularised punitive philosophies of modern times. ${ }^{61}$

Blindfolded justice - planted in the most visible sites of the boroughs -, now signals, evokes and adverts to the existence of a new European public order, whose jurisdiction is secular, implacable and immune to personal commitments. For this reason, Prof. Christian-Nils Robert

${ }^{60}$ Picture here: https://goo.gl/FzbWkY. Apart from Bern, the centres of Frankfurt, Nurnberg, Solothurn and Aarau also have Fountains of Justice (Gerechtigkeitsbrunnen or Justitiabrunnen). The fountain in Frankfurt (J. Hocheisen, 1611) has no blindfold, whereas the ones in Nurnberg (B. Wurzelbauer, 1585-1589), Solothurn (L. Perroud, 1561) and Aarau (H. Henz, 1643) are all blindfolded (Robert, Une Allégorie parfaite, 30-31, 73-74 and 87.

${ }^{61}$ Picture here: http://goo.gl/8Ye60B. Michel Porret, 'Mise en images de la procédure inquisitoire,' Sociétés \& Représentations 18, no. 2 (2004): 46. 
states that this image of martial blindfolded justice is one of the founding images of the modern state. ${ }^{62}$

It is right to say that blindfolded justice may be unbiased and free from the corruption of senses, but it (she) is not necessarily blind. ${ }^{63}$ With or without the blindfold, blindness was never believed to be a characteristic of justice. In Phaedrus, Plato proposed the distinction between the 'eyes of the soul' and 'eyes of the body', to denote the differences between essential or profound knowledge and unfinished or superficial knowledge; justice - be it worldly or divine - is seen as the virtue (in fact, one of the 'cardinal virtues', side by side with prudence, courage and temperance) of going further than the mere visible superficiality of facts, of things, of passions and circumstances. Many are the authors, by the way, that register this potentialising approximation between the inability to see and knowledge, underscoring many times that it is necessary not to see to be able to see better:

'Oedipus, for example, in Sophocles' tragedy, gives us (...) important elements for this analysis. (...) One of the highlights of this tragedy takes place when, 'seeing' that he'd had his own mother after killing his father, Oedipus awfully blinds himself. We might say that he blinded himself because he did not want to see it. However, in Heidegger's super sophisticated interpretation, Oedipus blinded himself to better be able to see his pathetic situation. ${ }^{64}$

62 Robert, Une Allégorie parfaite, 20.

63 Prosperi, Giustizia bendata, 10.

64 Affonso Romano de Sant'Anna, O Enigma Vazio: Impasses da Arte e da Crítica (Rio de Janeiro: Rocco, 2008) 11. Also referring to the blind who see more and better, innovative people such as Michel Reilhac, in France, or Andreas Heinecke, in Germany, have been 
Therefore, in order to overcome that dichotomy between blindfolded justice and the eyes of justice, what is visible and what is invisible, the superficial and the profound, some iconographic sources are doubtful as they represent the eyes of justice, as if they were trying to escape a simplifying or Manichaean dichotomy. There are interesting examples, old and new, of such enigmatic, polynomic and bipolar iconography, in which it is possible to affirm whether or not justice is blindfolded ${ }^{65}$ or if the blindfold is being put on or taken off, based on the incidence of wind. ${ }^{66}$

Still about duplicity, even though not as an element of doubt but rather an element of certainty, there are three very complex examples in antiquity. The first one is La Ivstice by Louis Testelin, possibly between 1680 and $1740 .{ }^{67}$ This allegory shows two childlike figures, one with

organising all around Europe over the past ten years a number of artistic and gastronomical experiences in total darkness, underscoring the tactile, olfactory, auditory and gustative sensations of the public. In 2004, Edouard de Broglie and Etienne Boisrond founded in Paris the restaurant Dans le Noir?, famous for serving haute cuisine in the dark. The concept of eating in the dark to potentialise taste came about shortly before that, in 1999, with the restaurant Blindekuh (German equivalent to Blind man's bluff), in Zurich, Switzerland.

${ }^{65}$ Cover of Tractatus de iudiciis by H. Vultejus (Hermanni Vulteji), 1654 (Cassellis: typis Salomonis Schadewitz: impensis Sebaldi Köleri) (http://goo.gl/2yA6f8). Justitia by Jost Amman for publisher Sigismund Feyrabend (circa 1564), mentioned in Otto Rudolf. Kissel, Die Justitia: Reflexionen über ein Symbol und seine Darstellung in der bildenden Kunst (München: C.H. Beck, 1997) 45 (https:// goo.gl/OdTvtM).

${ }^{66}$ Ivstitia ascribed to Flemish painter and engraver Jacob de Gheyn II, 1593 (http://goo.gl/YkMYyj).

${ }^{67}$ Picture here: https://goo.gl/Xks3CK. 
a blindfold and the other without, apparently pictured as a child and his guardian angel. Testelin gave blindfolded justice (the child) the sword, symbol of power and monopoly of legitimate violence of the State that applies the law. The other figure, justice without the blindfold (a calm guardian angel), which inspires, restrains and guides the impetus of the blindfolded child, has a scale, symbol of thoughtful judgement and reflection. Reflection and impetuosity, prudence and violence, reason and passion, Apollonian and Dionysian, all of these antithetical pairs emerge from Testelin's illustration but are far from constituting features typical of childlike figures. Here is another provocative paradox of art: convergent duplicity.

The second example of the affirmative duplicity in the pictorial discourse on justice is the image of the two-faced justice, like the Latin two-faced god Janus, by Joos Damhouder on the cover of the Praxis Rerum Criminalium, $1567 .{ }^{68}$ In that representation, justice looks to both sides simultaneously (four centuries ahead, Picasso would use this iconographic resource again!). Here again the justice without the blindfold has a sword whereas the one with the blindfold carries a scale.

The positive aspect in all such enigmatic, polysemic, ambivalent and bipolar representations resides in the fact that both this last two-faced representation of justice and those showing two justices - one with a blindfold and the

68 Double-faced justice in the book Praxis Rerum Criminalium, by Joost Damhoude (Antwerp: Joannem Bellerum ed., 1567, p. 433). See here: http://goo.gl/w163GP. 
other without - escape a true/false or positive/negative reductionist opposition in the juridical iconography. In this way, they assimilate the very complexity of the task of interpreting/applying law, which, after all, like the Latin Janus, is also a two-faced operation. That is, the person who interprets/applies the law must look at the past with one face - written law, the solidified preceding cases and the consolidated doctrine so far - in order to elucidate the given law up until that very instant whereas, with the other face, they must look to the future ahead and, therefore, seek improvement, reinventing and modernising the juridical order, or else allow law to disconnect from real life and lose its legitimacy and up-to-dateness. This constant relationship between the past, present and future of the juridical text is very well depicted in the last images herein discussed

As a matter of fact, this time continuum is not exclusive of juridicity. Paraphrasing Hans-Georg Gadamer, it may be said that the reality and the power of the enunciation both of law and the work of art 'cannot be reduced to the original historical horizon, in such a way that both law and art seem to 'have their own present', a 'timeless present', always up to date, always simultaneous, always evenly matched. ${ }^{69}$ In other words, this is the 'world's perpetual novelty', as stated by Alberto Caeiro (Fernando Pessoa) in 'O Guardador de Rebanhos' [The Shepherd] (1914). All in all, this is the difficult task of the

${ }^{69}$ Hans-Georg Gadamer, Hermenêutica da Obra de Arte (São Paulo: WMF Martins Fontes, 2010), 1-2. 
contemporary 'hermenaut', be it related to law or any of the fields of knowledge and art: to constantly and continually navigate between this dense network of meaning formed by past, present and future, reviewing, reappropriating, deviating, rediscovering, reducing, expanding or transposing contents so it does not lose its references or its up-to-dateness. With the typical wisdom of the great poets, Fernando Pessoa - once again - sums up very well the infinite constancy of this hermeneutical search in his poem 'A Montanha por Achar' [The Mountain to be Found], 1934:

If truth exists at all,

One shall see it is all about

The search for the truth,

Because life is all but half.

\section{Conclusion: Thinking Art; Feeling Law}

Despite all modern and contemporary rhetoric of the blindfold as a sign of impartiality and independence, up to today, the call for a clear and limpid sight of juridical events is still very present in the common sense of the population and in the imagery of justice. Both iconographic models of justice (with and without the blindfold) still coexist and debate in several fields of law: one example is the controversial value of proof that an 'eyewitness' still has today in criminal cases. Another particular fact is very eloquent in this regard: only in 2009 did the Brazilian Judiciary admit its first blind judge. He 
had been disqualified in the health check phase of a civil service exam twenty years before. ${ }^{70}$

Historically permeating virtue and vice, praise and criticism, wisdom and obtuseness, imagophilia and imagophobia, idolatry and iconoclasm, the blindfold of justice is, without a trace of doubt, an aesthetical element of great complexity. For many centuries justice was always represented with a limpid and sharp sight until the Protestant Reformation and the diffusion of the press in the sixteenth century came to consolidate the image of blindfolded justice. Justice always blindfolded - from then onwards - became the soul of the free city.

From those historical milestones, juridical rationality starts to have a predominantly textual form and to be hostile towards all that produces semantic uncertainty and conceptual openness, which leads to the growing disregard of the artistic image and recourse to nomophilia and nomolatry in positivist juridical rhetoric. ${ }^{71}$ As a matter of fact, since common sense started to see human reason as the only measure of all things, the disregard for art only grew. Not by chance, in the French courts of enlightened despotism, was the sad fable of the ant and the grasshopper, immortalised in the verses of Jean de La Fontaine, very popular.

However, nowadays, due to the huge visual appeal of our culture and, especially, due to juridical information

${ }^{70}$ In 1997, President Bill Clinton nominated blind lawyer Richard Conway Casey as Federal Judge at the District Court for the Southern District of New York, which generated controversy in the whole country.

${ }^{71}$ Robert Jacob, Images de la justice: essai sur l'iconographie judiciaire du Moyen âge classique (Paris: Léopard d’or, 1994), 165. 
itself, little by little law is becoming once again more pervious to arguments born in the visual, aesthetic or artistic spectrum. The countless forums of academic discussion (institutions, projects and publications) which care about this theme nowadays, and the ever more frequent presence at courts and hearing rooms of highly technological graphic schemes, CCTV camera images, magnetic resonance imaging or CAT scans and even $3 \mathrm{D}$ virtual scale models (as evidence or argumentation tools) - all this signals the presence of an 'iconic turn' or a 'pictorial turn' in our contemporary mediatic law.

After this more general register, one specific consideration on the blindfold of justice must be made: behind all the iconographic alternation seen throughout this text there is another debate, an epistemic-methodological aspect, which is much more relevant. First and foremost, the polysemy of the blindfold of justice throughout history reveals, in fact, that much more important than knowing if the best or most adequate iconography of justice is that with or without the blindfold, the question that matters to jurists and iconologists of law is the phenomenological issue of comprehending justice. The debate on the blindfold is, between the lines, a debate on the very issue of comprehending justice: what is truly understanding justice? How can someone comprehend it? Through sight? Through intellect? Through both? What is the best way to comprehend and feel it? Through the objective visual experience, be it the line or the letter, or through a reflection detached from the senses that deceive, corrupt and pervert us? Which is more relevant: seeing the (in) 
justice of things or listening to the (in)justice of things? It is the answer to these methodical-epistemological questions that is in the subtext of the iconographic debate reproduced throughout this text.

All these questions reveal that the precise moment when art and law cross ways is the complex moment of comprehension/interpretation: since they are cultural objects, art and law constantly reinvent, recreate, review and reinterpret the world and only make sense if they are interpreted/comprehended by their recipients. Art and law are the world's inventors and inventions, continuously disclosing the dialogue between man and reality. Therefore, both the work of art and the juridical norm are to be interpreted/comprehended, and are a way of interpreting and comprehending the world around. Law and art require this constant hermeneutical dimension of comprehension and interpretation. This comprehension/ interpretation is far from being static: it is inexhaustible, dynamic, alive, plural, reinventing and reviewing itself and updating at each moment.

The images that depict justice in its deepest entireness are those that put aside the mere debate on physiognomy, allegory, blindfold or eye, and underscore the very hermeneutic character and the dimension of comprehension/ interpretation/application of the juridical phenomenon.

This is precisely the intaglio engraving on the cover of Leggi e Costumi del Cambio che si Osservano nelle Principali Piazze di Europa e Singolarmente in quella di Livorno, a book by the commercial law specialist Pompeo 
Baldasseroni, published in 1784, in Pescia, by Stamperia di Gio. Tommaso Masi e Compagni. ${ }^{72}$

In this figure, with a humble look on her face, justice drops her sword and scale to talk with Hermes, the mythological Messenger of Olympus, about the tortuous paths of law and right. The Latin quote found below the engraving - 'qua te ducit uia dirige gressum' - is a passage from Virgil's Aeneid, Book I, line 401, meaning: 'Just proceed, and wherever the road takes you, direct your step. ${ }^{73}$ This Virgilian appeal quoted by Pompeo Baldasseroni may be understood today, more than anything else, as a call to remain on the hard path of hermeneutics, an undoubtedly laborious track, yet impossible to avoid, be it in law or in art. As Inocêncio Mártires Coelho says, 'any interpretation is always on its way (...) Interpretation meets no finish line. ${ }^{74}$

This hermeneutic approach reminds us of the beautiful fresco painted by Antonio Fedi at the Palazzo Pitti, Florence, $1815 .{ }^{75}$ That painting shows the god of justice with no blindfold, a witness of the world's injustice, next to Hermes, the messenger of Olympus, who - holding a caduceus - seems to guide her through the tortuous path

72 Picture here: https://goo.gl/xs6B3K

73 In Virgil's text, it is Venus, mother of Aeneas, disguised as a hunter, who advises her son to follow the path of righteousness and go meet Phoenician Queen Dido and ask her for help.

74 Inocêncio Mártires Coelho, Da hermenêutica filosófica à hermenêutica jurídica - fragmentos (São Paulo: Saraiva, 2010), 136.

75 Antonio Fedi (1771-1843), detail of the fresco Allegoria della Giustizia, painted in 1815, Salla della Giustizia, Palazzo Pitti, Florence (Italy). Here: https://goo.gl/h3utqP. 
of comprehension/interpretation/application of law. Once again there is constant wandering, no end or beginning.

For enticing and provoking the contemporary 'hermenaut' into deepening, refining, reviewing, radicalising, improving and restarting the constant and inexhaustible exercise of interpretation on the fabric of the unsaid, the work of art that has, perhaps, best translated all the complexity of justice so far is displayed precisely in the high relief sculpture La Giustizia, by Italian Livio Benetti, on show at the Museo Valtellinese di Storia ed Arte de Sondrio (Italy). It is a non-figurative work that, by bewildering the observer/reader, chooses to step away from the easy way of the 'prêt à penser. ${ }^{\text {76 }}$ Bewilderedment starts with the fact that La Giustizia is a contemporary work (19751976) even though it establishes a dialogue with many baroque elements: the folds and curves, the labyrinthine multiplicity, the fluidity of the mass, the rounded angles and corners, the swirly turbulent shapes, the overflowed matter. ${ }^{77}$ Livio Benetti's La Giustizia escapes the traditional and sensible associations with the heroic, mythical or religious themes that commonly represent justice.

What it indeed does - as it is difficult to read and as it deconstructs shared knowledge ${ }^{78}-$ is to arouse vigorous sensations, expressions and states of mind: awe, doubt, perplexity, admiration, astonishment, surprise,

${ }^{76}$ Livio Benetti (1915/1987), Virtú Cardinali: La Giustizia, 1975-1976, high-relief plaster cast, Museo Valtellinese di Storia ed Arte, Sondrio (Italy). Here: https://goo.gl/V3rUYJ

77 Gilles Deleuze, A Dobra - Leibniz e o Barroco (São Paulo: Papirus, 2009) 13-15.

${ }^{78}$ Paulo Ferreira da Cunha, Filosofia Jurídica Prática (Belo Horizonte: Fórum, 2009) 359. 
uneasiness, disorientation. These feelings that arise from the surprise at the unusual shapes and the expressiveness of the winding curves of the labyrinth-like sculpture Gadamer collected all these sensations under the concept of Betroffenheit - shatter the unshakeable certainties and make us, undoubtedly, remember that which Tobias Barreto - the great Brazilian writer and jurist - used to teach in the mid-nineteenth century: 'not only is law something that you know, it is something that you feel.' In addition, in the poetic wording of Justice Carlos Ayres Britto, of the Brazilian Federal Supreme Court, 'perhaps it is something one feels first of all or even before intelligence, for it cannot be forgotten that the noun 'sentence' itself comes from the verb to sense. ${ }^{79}$ Due to this indispensable sensitivity, law is far from being only 'sola escriptura'; law is also the constant search for the emotional intuition of righteousness. This is the lesson of Livio Benetti: prior to being read or looked at, justice must be felt.

\section{References}

Boehme-Nessler, Volker. BilderRecht: die Macht der Bilder und die Ohnmacht des Rechts. Heidelberg: Springer, 2010.

Brant, Sebastian. A nau dos insensatos. São Paulo: Octavo, 2010. Britto, Carlos Ayres. O Humanismo como Categoria Constitucional. Belo Horizonte: Fórum, 2007.

79 Carlos Ayres Britto, O Humanismo como Categoria Constitucional (Belo Horizonte: Fórum, 2007) 75. Feeling law is also the Leitmotiv of the poem Law, Like Love, by the Anglo-American poet W. H. Auden. 
Brunschwig, Colette R. 'Rechtsvisualisierung: Skizze eines nahezu unbekannten Feldes', MultiMedia und Recht 12, no. 1 (2009): IX-XII.

Chassan, Joseph-Pierre. Essai sur la symbolique du droit. Paris: Videcoq fils aîné, 1847.

Coelho, Inocêncio Mártires. Da hermenêutica filosófica à hermenêutica jurídica - fragmentos. São Paulo: Saraiva, 2010.

Cunha, Paulo Ferreira da. Filosofia Jurídica Prática. Belo Horizonte: Fórum, 2009.

Deleuze, Gilles. A Dobra - Leibniz e o Barroco. São Paulo: Papirus, 2009.

Deonna, Waldemar. Collections archéologiques et historiques: Moyen Age et temps modernes: Ville de Genève, Musée d'art et d'histoire. Genève: Musée d'art et d'histoire, 1929.

Déonna, Waldemar. Le Symbolisme de l'Eil. Paris: E. de Boccard, 1965.

Douzinas, Costas, and Lynda Nead. Law and the Image: the Authority of Art and the Aesthetics of Law. Chicago: University of Chicago Press, 1999.

Fiera, Battista and James Wardrop. De iusticia pingenda: A Dialogue between Mantegna and Momus = On the Painting of Justice. London: Lion and Unicorn Press, 1957.

Foucault, Michel. História da loucura na idade clássica. São Paulo: Perspectiva, 1978.

Frank, Jerome. 'Words and Music: Some Remarks on Statutory Interpretation.' Columbia Law Review 47, no. 8 (1947): 1259.

Gadamer, Hans-Georg. Hermenêutica da Obra de Arte. São Paulo: WMF Martins Fontes, 2010.

Gaucher, Charles-Étienne. Iconologie ou Traité des Allégories et Emblèmes (Paris: Lattré, 1791(?).

Jacob, Robert. Images de la justice: essai sur l’iconographie judiciaire du Moyen âge classique. Paris: Léopard d'or, 1994.

Kissel, Otto Rudolf. Die Justitia: Reflexionen über ein Symbol und seine Darstellung in der bildenden Kunst. München: C.H. Beck, 1997. 
Lacerda, Bruno Amaro and Monica Lopes Sette. Imagens da justiça. São Paulo: LTr, 2010.

Lopes, Mônica Sette. Uma metáfora: música \& direito. São Paulo: LTr, 2006.

Möller, Ernst von. 'Die Augenbinde der Justitia', Zeitschrift für Christliche Kunst 18, no. 4, (1905).

Ost, François. Contar a lei: as fontes do imaginário jurídico. São Leopoldo, RS: UNISINOS, 2007.

Panofsky, Erwin. Studi di iconologia: i temi umanistici nellarte del Rinascimento. Torino: Einaudi, 1999.

Prinz, Stephan. Juristische Embleme: Rechtsmotive in den Emblemata des 16. bis 18. Jahrhunderts. Berlin: Lit, 2009.

Prosperi, Adriano. Giustizia bendata: percorsi storici di un'immagine. Torino: G. Einaudi, 2009.

Ripa , Cesare. Iconologia. Roma: heredi di Gio. Gigliotti, 1593.

Robert, Christian-Nils. Une Allégorie parfaite: La Justice: vertu, courtisane et bourreau. Genève: Georg, 1993.

Robilant, Anna Di. 'The Aesthetics of Law.' Global Jurist Advances 1, no. 2 (2001).

Rodolfo Sacco, 'Mute Law'. The American Journal of Comparative Law 43, no. 3 (1995): 455.

Sant'Anna, Affonso Romano de. O Enigma Vazio: Impasses da Arte e da Crítica. Rio de Janeiro: Rocco, 2008.

Schapiro, Meyer. Mondrian: a dimensão humana da pintura abstrata. São Paulo: Cosac \& Naify, 2001.

Stolleis, Michael. L'Eil de la Loi Veille - Histoire d'une Métaphore. Paris: Mille et Une Nuits, 2006.

Vismann, Cornelia. 'Image and Law - a Troubled Relationship, Parallax 14, no. 4 (2008).

Wieacker, Franz. História do direito privado moderno. Lisboa: Fundação Calouste Gulbenkian, 1980. 